\title{
Suicide Tendency among Widow and Non Widow Women
}

\author{
Dr. D. A. Dadhania ${ }^{1}$
}

\section{ABSTRACT}

Purpose of this research is to comparative study of suicide tendency among widow and non widow women. The sample consisted of 80 women out which 40 were widow women and 40 non widow women. Collected data from the women as suicide tendency scale of Dr. R. G. Meghnathi. The obtained data were analyzed though " $t$ " test to know the mean difference between the two groups widow women and non widow women in Rajkot city (Gujarat). The results show that there is significant difference in the suicide tendency level of the widow women and non widow women.

\section{Keywords: Suicide Tendency,}

Suicide, also known as completed suicide, is the "act of taking one's own life". Attempted suicide or non-fatal suicidal behavior is self-injury with the desire to end one's life that does not result in death. Assisted suicide is when one individual helps another bring about their own death indirectly via providing either advice or the means to the end. This is in contrast to euthanasia, where another person takes a more active role in bringing about a person's death. Suicidal ideations is thoughts of ending one's life but not taking any active efforts to do so. There is discussion about the appropriateness of the term commit and its use to describe suicide. Those who object to the use of commit argue that it carries with it implications that suicide is a criminal, sinful or morally wrong act. There is growing consensus that it is more appropriate to use "completed suicide," died by suicide or simply "killed him/herself" to describe the act of suicide. Despite this, "committed suicide" or similar descriptions are the most common in both scholarly research and journalism. Suicide is the act of deliberately killing oneself. Risk factors for suicide include mental disorder (such as depression, personality disorder, alcohol dependence, or schizophrenia), and some physical illnesses, such as neurological disorders, cancer, and HIV infection. There are effective strategies and interventions for the prevention of suicide.

\footnotetext{
${ }^{1}$ Associate Professor, Department Of Psychology, Shri V. M. Mehta Municipal Arts College, Jamnagar
} 
Hinduism does not approve suicide. Hindus believe that human life is very precious, which is attainted after after hundreds and thousands of births and provides an unique opportunity to each individual to make a quantum jump into higher planes of existence or attain immortality. Even gods and other celestial beings do not have this opportunity unless they come down to earth and take birth as human beings.

The story of suicide is probably as old as that of man himself. Through the ages, suicide has variously been glorified, romanticized, bemoaned, and even condemned. Be it the tragic Greek heroes Aegeus, Lycurgus, Cato, Socrates, Zeno, Demosthenes or Seneca; or the Roman figures Brutus, Cassius, Mark Anthony or the Egyptian princess, Cleopatra; or Samson, Saul, Abimelech and Achitophel of the Old Testament; or the suicide bombers in the present world, the universality of suicide transcends religion and culture.

An understanding of suicide in the Indian context calls for an appreciation of the literary, religious, and cultural ethos of the subcontinent because tradition has rarely permeated the lives of people for as long as it has in India. Ancient Indian texts contain stories of valor in which suicide as a means to avoid shame and disgrace was glorified. Suicide has been mentioned in the great epics of Ramayana and Mahabharata. When Lord Sri Ram died, there was an epidemic of suicide in his kingdom, Ayodhya. The sage Dadhichi sacrificed his life so that the Gods may use his bones in the war against the demons. The Bhagavad Gita condemns suicide for selfish reasons and posits that such a death cannot have "shraddha', the all-important last rites. Brahmanical view had held that those who attempt suicide should fast for a stipulated period. Upanishads, the Holy Scriptures, condemn suicide and state that 'he who takes his own life will enter the sunless areas covered by impenetrable darkness after death'.

However, the Vedas permit suicide for religious reasons and consider that the best sacrifice was that of one's own life. Suicide by starvation, also known as 'sallekhana', was linked to the attainment of 'moksha' (liberation from the cycle of life and death), and is still practiced to this day.Sati, where a woman immolated herself on the pyre of her husband rather than live the life of a widow and Jahuar (Johar), in which Rajput women killed themselves to avoid humiliation at the hands of the invading Muslim armies, were practiced until as recently as the early half of the $20^{\text {th }}$ century; stray cases continue to be reported*

\section{OBJECTIVE:-}

The purpose of present investigation was to investigate symptoms of suicide tendency in widow women and non widow women.

\section{HYPOTHESIS:-}

- To study the suicide tendency of widow women.

- To study the suicide tendency of non widow women. 
- To study the difference between suicide tendency among widow women and non widow women.

\section{VARIABLE:-}

- INDEPENDENT VARIBLE -

Widow women and non widow women.

- DEPENDENT VARIBLE-

Score on suicide tendency scale.

\section{SAMPLE:-}

The sample of present study consisted 80 people living in the Rajkot city (Gujarat). It consisted 40 widow women and 40 non widow women.

\section{TOOLS:-}

In this study suicide tendency scale developed by Dr. R.G. Meghnathi was used.

\section{STATISTICAL ANALYSIS:-}

' $t$ ' test was applied to know the difference between the suicide tendency level of widow women and non widow women

\section{TABLE}

\begin{tabular}{|l|l|l|l|l|l|}
\hline Group & $\mathrm{N}$ & MEAN & SD & $\mathrm{t}$ & Sing. \\
\hline $\begin{array}{l}\text { Widow } \\
\text { women }\end{array}$ & 40 & 89.44 & 14.84 & $2.70^{* *}$ & 0.01 \\
\hline $\begin{array}{l}\text { Non widow } \\
\text { women }\end{array}$ & 40 & 81.06 & 12.80 & & \\
\hline
\end{tabular}

The above table shows the levels of suicide tendency of widow women and non widow women. Where in widow women mean is 89.44 where as for non widow women it is 81.06 and SD14.84 and 12.80 for both castes. ' $t$ ' level value is 2.70 and its level of sig is 0.01 " $t$ " score of widow women and non widow women is 8.00 it is more than critical value $2.59(0.01)$. So it is significant. 


\section{CONCLUSION:-}

There was significant difference between widow women and non widow women regarding the level of suicide tendency. It means level of suicide tendency more in widow women.

\section{REFERENCE:-}

"Maine Suicide Prevention Website". Maine.gov. Retrieved 2012-01-15.

Jump up_ January 15, 2012 (2003-09-16). "Suicide prevention definition - Medical Dictionary definitions of popular medical terms easily defined on MedTerms". Medterms.com. Retrieved 2012-01-15.

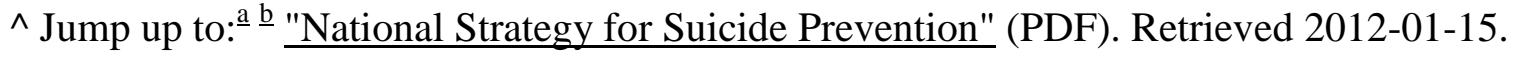

Jump up_^ "Suicide Prevention: at what level does it work?", Bertolote, Jose. World Psychiatry.

2004 October; 3(3): 147-151.

Jump up_ R. F. W. Diekstra. Preventive strategies on suicide.

Preventing Suicide - A Resource for Primary Health Care Workers" (PDF), World Health Organization, Geneva, 2000, p. 13.

Jump up_ Office of the Surgeon General:The Surgeon General's Call To Action To Prevent Suicide 1999.

Jump up^_ Rory C. O'Connor, Stephen Platt, Jacki Gordon: International Handbook of Suicide Prevention: Research, Policy and Practice, p. 510. 